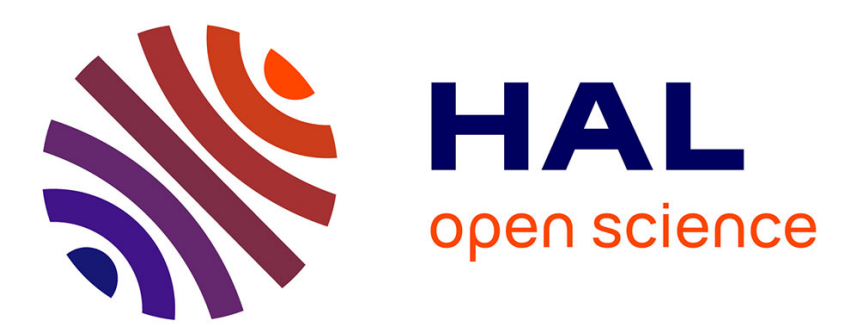

\title{
A simple, rapid and efficient way to obtain infectious clones of potyviruses
}

Cecile Desbiez, Charlotte Chandeysson, Hervé Lecoq, Benoît Moury

\section{To cite this version:}

Cecile Desbiez, Charlotte Chandeysson, Hervé Lecoq, Benoît Moury. A simple, rapid and efficient way to obtain infectious clones of potyviruses. Journal of Virological Methods, 2012, 183 (1), pp.94-97. 10.1016/j.jviromet.2012.03.035 . hal-02644385

\section{HAL Id: hal-02644385 \\ https://hal.inrae.fr/hal-02644385}

Submitted on 28 May 2020

HAL is a multi-disciplinary open access archive for the deposit and dissemination of scientific research documents, whether they are published or not. The documents may come from teaching and research institutions in France or abroad, or from public or private research centers.
L'archive ouverte pluridisciplinaire HAL, est destinée au dépôt et à la diffusion de documents scientifiques de niveau recherche, publiés ou non, émanant des établissements d'enseignement et de recherche français ou étrangers, des laboratoires publics ou privés. 
Version définitive du manuscrit publié dans / Final version of the manuscript published in : Journal of Virological Methods, 2012, 183, 94-97, http://dx.doi.org/10.1016/j.jviromet.2012.03.035.

\title{
A simple, rapid and efficient way to obtain infectious clones of potyviruses \\ C. Desbiez*, C. Chandeysson, H. Lecoq, B. Moury
}

INRA, UR 407 Pathologie végétale, F-84143 Montfavet, France

*Corresponding author. Phone: (33)432722807. Fax: (33)432722842. E-mail: desbiez@avignon.inra.fr

\begin{abstract}
The availability of an infectious cDNA clone is a prerequisite for genetic studies on RNA viruses. However, despite important improvement in molecular biology techniques during the last decades, obtaining such clones often remains tedious, time-consuming and rather unpredictable. In the case of potyviruses, cDNA clones are frequently unstable due to the toxicity of some viral proteins for bacteria. The problem can be overcome by inserting introns into the viral sequence but this requires additional steps in the cloning process and depends on the availability of suitable restriction sites in the viral sequence or adjunction of such sites by mutagenesis. Homologous recombination in yeast rather than in vitro restriction and ligation can be used to build infectious clones or other viral constructs. This paper describes how, by using recombination in yeast and fusion PCR, infectious intron-containing clones were obtained within a few weeks for two strains of watermelon mosaic virus (WMV, Potyvirus), whereas previous attempts using "classical” cloning techniques had failed repeatedly. Using the same approach, intronless infectious clones of two other potyviruses, zucchini yellow mosaic virus (ZYMV) and papaya ringspot virus (PRSV), were obtained in less than two weeks.
\end{abstract}

Keywords: plant ssRNA virus; potyvirus; infectious clone; intron; cloning in yeast 
Version définitive du manuscrit publié dans / Final version of the manuscript published in : Journal of Virological Methods, 2012, 183, 94-97, http://dx.doi.org/10.1016/j.jviromet.2012.03.035.

The molecular tools for manipulating RNA remain scarce. Infectious cDNA clones have therefore been developed in the last 30 years for genetic studies of plant RNA viruses. For potyviruses, that represent about $25 \%$ of all known plant viruses, the first infectious clone was obtained in 1989 (Domier et al., 1989). More than 20 years later, about 40 clones belonging to 15 different virus species are now available, and such tools are still missing for many agronomically important viruses. Among the difficulties relevant to the building of potyvirus infectious clones are the length of the viral RNA (about 10 kilobases, making one-step cloning poorly efficient), the highly deleterious effects of adding any extra nucleotides in the 5' or 3' extremity of the genome during the cloning process (Boyer and Haenni, 1994), and the toxicity of some viral proteins in Escherichia coli, resulting in spontaneous deletions of some clones in bacterial cells. The most toxic proteins appear to be P3 and CI encoded in the central region of the genome (Jakab et al., 1997; Chikh Ali et al., 2011). In order to overcome these difficulties, several techniques have been used, including cloning the genome in two halves that have to be religated in vitro before inoculation (Jakab et al., 1997), adding introns in the cDNA to prevent expression in E. coli (Johansen, 1996), or removing cryptic prokaryotic promoter elements in the P3 coding region by site-directed mutagenesis (Chikh Ali et al., 2011). One drawback of these techniques, besides the fact that they are time-consuming, is the risk of adding unwanted mutations in extensively manipulated clones, resulting in non-infectivity or impaired biological properties. To limit theses drawbacks, a simple protocol involving a very limited number of cloning steps and proven to be very efficient was developed.

Purified virions of strains WMV-FMF00-LL2 and WMV-FMF00-LL1 (Desbiez et al., 2007) obtained with standard protocols applied in the laboratory (Lecoq and Pitrat, 1985) immediately before use (in the case of FMF00-LL2) or kept in glycerol $(1: 1 \mathrm{vol}: \mathrm{vol})$ at $-20^{\circ} \mathrm{C}$ for 2 years were used for the production of viral RNA. The virus particles were precipitated by ultracentrifugation for $2 \mathrm{~h}$ at $130000 \mathrm{~g}$ in a Beckman LE-80 ultracentrifuge with a 50.2Ti rotor, and resuspended in $0.02 \mathrm{M}$ potassium phosphate buffer at $\mathrm{pH}$ 7.4. One $\mu \mathrm{g}$ of purified virus was subjected to a Proteinase $\mathrm{K}$ treatment for $40 \mathrm{~min}$ at $37^{\circ} \mathrm{C}(100 \mu \mathrm{M}$ Proteinase $\mathrm{K}$ in buffer Tris $10 \mathrm{mM}$, EDTA 5 $\mathrm{mM}$, SDS $0.5 \% \mathrm{pH} 8$ ), then to one phenol extraction followed by a phenol: chloroform: isoamylate (25:24:1) extraction, ethanol precipitation and resuspension in $20 \mu 1$ RNAse-free water. Viral genomes were amplified in four overlapping fragments of 1.9 to $3.5 \mathrm{~kb}$ using specific primers with at least a 20-base overlap (Fig. 1, Table 1). The primers corresponding to the 5' and 3' extremities of the genome contained an extra 20- to 30-base tail corresponding to the extremities of the vector (see below). Reverse transcription reactions were performed on $2 \mu 1$ RNA, using 2.5 U AMV reverse transcriptase (Promega, France) in the manufacturer's buffer, $0.5 \mathrm{mM}$ each dNTP, and 0.5 $\mu \mathrm{M}$ reverse primers WMV-A-RV, C-RV, E-RV and F-RV (Table 1). The reactions were performed for $1 \mathrm{~h}$ at $42^{\circ} \mathrm{C}$. Two $\mu 1$ of each cDNA were used for PCR amplification using 1-2 U Pfu DNA polymerase (Promega, France) with $0.2 \mathrm{mM}$ of each $\mathrm{dNTP}$ and $0.5 \mu \mathrm{M}$ of each primer. PCR reactions were performed as follows: $5 \mathrm{~min}$ at $95^{\circ} \mathrm{C}$, followed by 35 cycles of $45 \mathrm{~s}$ at $95^{\circ} \mathrm{C}, 45 \mathrm{~s}$ at $50^{\circ} \mathrm{C}$ and $5 \mathrm{~min}$ at $72^{\circ} \mathrm{C}$. PCR fragments of the expected sizes were excised from $1 \%$ agarose gel under UV light and purified using standard protocols.

For WMV, numerous attempts had shown that viral clones were highly unstable in E. coli (Desbiez, unpublished), and the insertion of introns was chosen as a way to improve the stability of bacterial clones as used by Johansen (1996) for pea seedborne mosaic virus. Introns IV (189 bp) of the STLS1 gene from Solanum tuberosum ("Intron 1" in this work) and Intron $2(221 \mathrm{pb})$ of the NiR gene from Phaseolus vulgaris (Johansen, 1996) were amplified from an intron-containing infectious clone of potato virus Y (PVY) SON41p (Moury et al., 2004), using primers "WMV-B-FW + WMV-B-RV" and "WMV-D-FW + WMV-D-RV" containing a 30-base tail complementary to the genome of WMV at positions 3541 and 5397 in the P3 and CI coding regions respectively (Table 1). Amplified fragments $\mathrm{B}$ and $\mathrm{D}$ (corresponding to introns 1 and 2, respectively) were fused to fragments C and E, respectively, by fusion PCR (Fig. 1): $0.2 \mu 1$ of fragments "B and C" and "D and 
Version définitive du manuscrit publié dans / Final version of the manuscript published in : Journal of Virological Methods, 2012, 183 94-97, http://dx.doi.org/10.1016/j.jviromet.2012.03.035.

E", respectively, were used in a mix containing 1-2 U Pfu in the manufacturer's buffer, $0.2 \mathrm{mM}$ of each dNTP, $0.5 \mu \mathrm{M}$ each of primers "WMV-B-FW + WMV-C-RV" and "WMV-D-FW + WMV-ERV". The amplification conditions were as above with elongation times of 4 min. Fragments of the expected size were excised from agarose gels and purified.

To prepare the vector, a construct containing the full-length clone of PVY SON41p in pAGUS1 (Johansen, 1996; Moury et al., 2004), containing the $2 \mu$ yeast replication origin and Trp- 1 promoter and gene as a selectable marker (Sikorski and Hieter, 1989) was digested with PflFI and NcoI in order to excise almost completely the PVY insert. The $5.5 \mathrm{~kb}$ fragment corresponding to the vector was excised from an agarose gel and purified.

The diploid Saccharomyces cerevisiae strain YPH501 (YPH500xYPH499) (MATa/MATa ura352/ura3-52 lys2-801_amber/lys2-801_amber ade2-101_ochre/ade2-101_ochre trp1- $\Delta 63 /$ trp1- $\Delta 63$

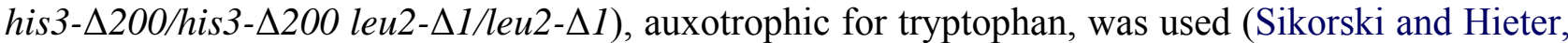
1989). Yeast cultures were grown at $28^{\circ} \mathrm{C}$ in YPD medium (1\% yeast extract, $2 \%$ peptone, $2 \% \mathrm{D}$ glucose) prior to transformation and in CAU selective medium $(0.1 \%$ casamino acid containing no tryptophan, $0.67 \%$ yeast nitrogen base without amino acids, $0.0025 \%$ adenine sulfate, $0.0025 \%$ uracil, 2\% D-glucose) after transformation. Preparation of competent cells and transformation were performed using a protocol derived from Klebe et al., 1983. Briefly, yeasts were grown in $500 \mathrm{ml}$ YPD medium at $30^{\circ} \mathrm{C}$ with agitation, until absorbance at $600 \mathrm{~nm}$ reached 0.6 . The cells were centrifuged for $3 \mathrm{~min}$ at room temperature and resuspended in $250 \mathrm{ml}$ of SBEG (sorbitol $1 \mathrm{M}$, bicine $\mathrm{pH} 8.510 \mathrm{mM}$, ethylene glycol 3\%) After a second centrifugation, the cells were resuspended in $5 \mathrm{ml} \mathrm{SBEG}$, and aliquots of $100 \mu \mathrm{l}$ were stored at $-80^{\circ} \mathrm{C}$ until use.

For transformation, $100 \mu \mathrm{l}$ of competent yeast cells were mixed with $7 \mu \mathrm{l}$ of sonicated heatdenaturated salmon sperm DNA $(10 \mathrm{mg} / \mathrm{ml})$ as a carrier and $15 \mu \mathrm{l}$ of vector+insert DNA containing approximately the same amount of the different insert fragments (about $100 \mathrm{ng}$ ), with a vector:insert ratio of 1:3. Eight hundred $\mu 1$ of PEG4000 (polyethylene glycol $40 \%$, bicine $10 \mathrm{mM}, \mathrm{pH} 8.35$ ) were added, and the cells were incubated for one hour at $30^{\circ} \mathrm{C}$ with gentle agitation. The cells were collected by centrifugation for $5 \mathrm{~min}$ at $2600 \mathrm{~g}$, and the pellet was resuspended in $1 \mathrm{ml} \mathrm{NB}$ buffer $(\mathrm{NaCl} 0.15 \mathrm{M}$, bicine $10 \mathrm{mM}, \mathrm{pH} 8.35)$. After $5 \mathrm{~min}$ of centrifugation at $2600 \mathrm{~g}, 900 \mu \mathrm{l}$ of the supernatant was discarded; the cells were resuspended in the remaining $100 \mu \mathrm{l}$, plated on CAU solid medium (containing $2 \%$ bacto-agar) and grown at $30^{\circ} \mathrm{C}$ for at least $48 \mathrm{~h}$.

Yeast colonies ( 3 to 4 colonies per transformation) were inoculated in $3 \mathrm{ml}$ of liquid CAU medium and grown overnight at $28^{\circ} \mathrm{C}$. Plasmid DNA was isolated according to Hoffman and Winston (1987). Briefly, the cells were collected by centrifugation and resuspended in $200 \mu \mathrm{l}$ of a buffer containing 2\% Triton $\mathrm{X}-100,1 \%$ SDS, $100 \mathrm{mM} \mathrm{NaCl}, 10 \mathrm{mM}$ Tris $\mathrm{pH} 8,1 \mathrm{mM}$ EDTA. Two hundred $\mu \mathrm{l}$ of phenol:chloroform:isoamylic alcohol (50:49:1) and $0.3 \mathrm{~g}$ of $0.45 \mathrm{~mm}$ acid-washed glass beads (Sigma) were added, and the suspension was vigorously shaken for $5 \mathrm{~min}$. The DNA was recovered by ethanol precipitation, resuspended in $10 \mu \mathrm{l}$ of de-ionized water, desalted on a Millipore $\mathrm{MF}^{\mathrm{TM}} 0.025 \mu$ membrane filter and used for transformation of electrocompetent $E$. coli DH5 according to standard protocols. Bacterial plasmid DNA was extracted by alkaline lysis and the screening was performed by restriction enzyme analysis.

The plasmids were inoculated with a HandGun according to Gal-On et al. (1995) to 10 susceptible zucchini squash F1 Diamant plantlets at the cotyledon stage. Six independent clones were pooled for the first bombardment, using approximately $30 \mathrm{ng}$ DNA per clone, in order to determine if there was at least an infectious clone among them. Three and 8 plants were positive after inoculation with FMF00-LL2 and FMF00-LL1, respectively, as defined by symptom observation and serological (ELISA) tests with a WMV polyclonal antiserum. In a second step, each clone was inoculated individually to 10 zucchini plantlets, and symptoms were checked visually two weeks after inoculation. Viral infection was confirmed by ELISA tests. Two and 4 out of 6 clones each were found to be infectious for FMF00-LL2 and FMF00-LL1 respectively. The presence of the expected viral strain was checked in symptomatic plants by RNA extraction, RT-PCR and partial sequencing 
Version définitive du manuscrit publié dans / Final version of the manuscript published in : Journal of Virological Methods, 2012, 183, 94-97, http://dx.doi.org/10.1016/j.jviromet.2012.03.035.

according to standard protocols (Desbiez et al., 2007). Symptoms observed after bombardment of the infectious clones and subsequent mechanical inoculations were indistinguishable from those induced by the wild-type isolates. There was no delay in the appearance of symptoms after mechanical inoculation from zucchini plants infected with the clones compared to those infected by wild-type viruses (data not shown). The host range of the infectious clones appeared similar to that of the natural isolates (data not shown), with FMF00-LL1 being systemic on Ranunculus sardous but not on Chenopodium quinoa, and FMF00-LL2 being systemic on $C$. quinoa but not on $R$. sardous (Lecoq et al., 2011).

For ZYMV and PRSV, since several infectious intronless clones have already been obtained and are satisfactorily stable (Gal-On et al., 1991; Lin et al., 2002; Chiang and Yeh, 1997; Chen et al., 2008), it could be expected that clones of these viruses would not require introns. Consequently, a simplified cloning strategy was used. RNA was extracted from purified virions of two reference isolates from France, ZYMV-E15 (Lecoq and Pitrat, 1984) and PRSV-E2 (Lecoq et al., 1982), stored in $50 \%$ glycerol at $-20^{\circ} \mathrm{C}$ for more than 15 years, as for WMV. Four overlapping fragments of about $2.5 \mathrm{~kb}$ each were amplified by RT-PCR as above, purified on gel and used for yeast transformation with the same vector as for WMV. Four yeast colonies for each virus were grown in liquid CAU medium; DNA was extracted as for WMV and used for transformation of $E$. coli. Since the complete sequences of ZYMV-E15 and PRSV-E2 had not been established beforehand and their restriction profiles were not known, bacterial plasmid DNA was digested with EcoRI. This enzyme was chosen because 3 to 6 EcoRI restriction sites are usually present in the full-length sequences of ZYMV and PRSV available in databases (data not shown). Clones displaying a total size of about $15 \mathrm{~kb}$ were used for bombardment as for WMV. In a first assay, a pool of 3 clones for each virus was used and was shown to be infectious by symptom observation and serological tests. After separate bombardments, 2 and 1 clones were infectious for ZYMV and PRSV, respectively. The symptoms induced by the cloned cDNAs were indistinguishable from those of wild-type strains. Pathotypes of cloned ZYMV-E15 on melon lines carrying the Fn or Zym genes (Lecoq and Pitrat, 1984) were identical to those of wild-type ZYMV-E15 (data not shown). In both cases, the whole cloning process from RNA purification to plant bombardment took about 10 days. The PCR steps were performed from previously obtained purified viruses that were available, which may have improved the PCR efficiency due to the purity of the RNA used, as well as the infectivity of the clones obtained since only RNAs that had been able to be encapsidated were involved in the amplification and cloning processes. The PCR steps worked satisfactorily with total RNA of infected plants (data not shown), but the percentage of fragments containing highly deleterious or lethal mutations in this case is not known. Using immunocapture (Wetzel et al., 1992) before the RT-PCR may allow selection of only encapsidated RNA in the amplification procedure without requiring a virus purification step.

As a whole, this cloning strategy did not involve any exceptional techniques, but it was surprisingly rapid and efficient. The insertion of introns has already been used for stabilizing cDNA clones of several potyviruses (Johansen 1996; Lopez-Moya et al., 2002, Moury et al., 2004) even if they were inserted step by step using ligation in suitable restriction sites. Homologous recombination in yeast rather than ligation in bacteria has also proved useful for generating recombinant clones of plant viruses (Fernandez-Delmond et al., 2004; Liang et al., 2004) Infectious clones of apple chlorotic leaf spot virus have been recently obtained by one-step cloning of the $7.5 \mathrm{~kb}$ genome in an agroinfiltration vector (Youssef et al., 2011). Yeast transformation with 4 insert fragments $(2.5 \mathrm{~kb}$ each) and 1 vector yielded good results, with 30 to 50 yeast colonies obtained per transformation. In another attempt, transformation with 5 insert fragments of 1.5 to $2.5 \mathrm{~kb}$ resulted in about 20 colonies (data not shown). On the other hand, a first attempt of cloning for WMV with 1 vector, 4 virus fragments $(2.5 \mathrm{~kb}$ each) and 2 intron fragments $(200 \mathrm{pb}$ each) did not yield any colonies. It is not known whether this failure was related to the number of recombining fragments, or to the small size of the introns. An argument against the first hypothesis is the fact that a complete mycoplasma 
Version définitive du manuscrit publié dans / Final version of the manuscript published in : Journal of Virological Methods, 2012, 183, 94-97, http://dx.doi.org/10.1016/j.jviromet.2012.03.035.

genome was recently obtained by homologous recombination in yeast of 25 genomic fragments (Gibson et al., 2008). In this work, fusion PCR was a way to overcome the problem.

The percentage of infectious clones obtained among the ones generated was from $30 \%$ to $60 \%$ in the conditions used. The actual percentage may be slightly higher, the "non-infectivity" could be related in some cases to non-optimal concentration of the plasmid DNA or inoculation conditions. However an infectivity of about $50 \%$ probably reflects the ratio of infectious to non-infectious genomes in the original virus population, since potyviruses, with a genome of $10 \mathrm{~kb}$, have a mutation rate in the order of magnitude of $10^{-4}$ mutations/genome/replication cycle (Sanjuan et al., 2010), and more than half of these mutations are lethal or significantly deleterious (Carrasco et al., 2007). Testing a sufficient number of clones ( 3 to 6 clones here) can overcome the problem. In classic cloning procedures, this would mean handling a large and sometimes exponentially-growing number of constructs during the cloning process, but with this protocol involving a very limited number of steps, the number of clones that can be tested is not a limiting factor.

This work very likely represents the first time that infectious potyvirus cDNA clones are obtained repeatedly in less than 2 weeks starting almost from scratch. This simple technique opens very promising perspectives to obtain routinely infectious clones for other potyviruses.

\section{References:}

Boyer, J.-C., Haenni, A.-L., 1994. Infectious transcripts and cDNA clones of RNA viruses. Virology 198, 415-426.

Carrasco, P., de la Iglesia, F., Elena, S.F., 2007. Distribution of fitness and virulence effects caused by single-nucleotide substitutions in Tobacco etch virus. J. Virol. 81, 12979-12984.

Chiang, C. H., Yeh, S. D. 1997. Infectivity assays of in vitro and in vivo transcripts of papaya ringspot potyvirus. Bot. Bull. Acad. Sinica 38:153-163.

Chen, K.C., Chiang, C.H., Raja, J.A., Liu, F.L., Tai, C.H., Yeh, S.-D., 2008. A single amino acid of NIaPro of Papaya ringspot virus determines host specificity for infection of papaya. Mol. Plantmicrobe Interact. 21, 1046-1057.

Chikh Ali, M., Said Omar, A., Natsuaki, T., 2011. An infectious full-length cDNA clone of potato virus YNTN-NW, a recently reported strain of PVY that causes potato tuber necrotic ringspot disease. Arch. Virol. 156, 2039-2043.

Desbiez, C., Costa, C., Wipf-Scheibel, C., Girard, M., Lecoq, H., 2007. Serological and molecular variability of watermelon mosaic virus (genus Potyvirus). Arch. Virol. 152, 775-781.

Domier, L.L., Franklin, K.M., Hunt, A.G., Rhoads, R.E, Shaw, J.G., 1989. Infectious in vitro transcripts from cloned cDNA of a potyvirus, tobacco vein mottling virus. Proc. Natl. Acad. Sci. U.S.A 86, 3509-3513.

Fernandez-Delmond, I., Pierrugues, O., de Wispelaere, M., Guilbaud, L., Gaubert, S., Divéki, Z., Godon, C., Tepfer, M., Jacquemond, M., 2004. A novel strategy for creating recombinant infectious RNA virus genomes. J. Virol. Methods 121, 247-257.

Gal-On, A., Antignus, Y., Rosner, A., Raccah, B., 1991. Infectious in vitro RNA transcripts derived from cloned cDNA of the cucurbit potyvirus, zucchini yellow mosaic virus. J. Gen. Virol. 72, 2639-2643.

Gal-On, A., Meir, E., Huet, H., Hua, W.J., Raccah, B., Gaba, V., 1995. Particle bombardment drastically increases the infectivity of cloned DNA of zucchini yellow mosaic potyvirus. J. Gen. Virol. 76, 3223-3227.

Gibson, D.G., Benders, G.A., Axelrod, K.C., Zaveri, J., Algire, M.A., Moodie, M., Montague, M.G., Venter, J.C., Smith, H.O., Hutchison, C.A., 2008. One-step assembly in yeast of 25 overlapping DNA fragments to form a complete synthetic Mycoplasma genitalium genome. Proc. Natl. Acad. Sci. U.S.A 105, 20404-20409.

Hoffman, C.S, Winston, F., 1987. A ten-minute DNA preparation from yeast efficiently releases autonomous plasmids for transformation of Escherichia coli. Gene 57, 267-272. 
Jakab, G., Droz, E., Brigneti, G., Baulcombe, D.C., Malnoë, P., 1997. Infectious in vivo and in vitro transcripts from a full-length cDNA clone of PVY-N605, a Swiss necrotic isolate of potato virus Y. J. Gen. Virol. 78, 3141-3145.

Johansen, E., 1996. Intron insertion facilitates amplification of cloned virus cDNA in Escherichia coli while biological activity is reestablished after transcription in vivo. Proc. Natl. Acad. Sci. U.S.A 93, 12400-12405.

Klebe, R.J., Harriss, J.V., Sharp, D., Douglas, M.G., 1983. A general method for polyethyleneglycol-induced genetic transformation of bacteria and yeast. Gene 25, 333-341.

Lecoq, H., Lot, H., Pitrat, M., 1982. Mise en évidence du virus de la mosaïque de la pastèque type 1 (WMV-1) dans le Sud-Est de la France. Agronomie 1, 827-834.

Lecoq, H., Pitrat, M., 1984. Strains of zucchini yellow mosaic virus in muskmelon (Cucumis melo L.). J. Phytopathol. 111, 165-173.

Lecoq, H., Pitrat, M., 1985. Specificity of the helper-component-mediated aphid transmission of three potyviruses infecting muskmelon. Phytopathology 75, 890-893.

Lecoq, H., Fabre, F., Joannon, B., Wipf-Scheibel, C., Chandeysson, C., Schoeny, A., and Desbiez, C., 2011. Search for factors involved in the rapid shift in watermelon mosaic virus (WMV) populations in south-eastern France. Virus Res. 159, 115-123.

Liang, D., Gray, S.M., Kaplan, I., Palukaitis, P., 2004. Site-Directed Mutagenesis and Generation of Chimeric Viruses by Homologous Recombination in Yeast to Facilitate Analysis of Plant-Virus Interactions. Mol. Plant-microbe Interact. 17, 571-576.

Lin, S.-S., Hou, R.F., Yeh, S.-D., 2002. Construction of in vitro and in vivo infectious transcripts of a Taiwan strain of Zucchini yellow mosaic virus. Bot. Bull. Acad. Sin. 43, 261-269.

Lopez-Moya, J.J., Garcia, J.A., 2000. Construction of a stable and highly infectious introncontaining cDNA clone of plum pox potyvirus and its use to infect plants by particle bombardment. Virus Res. 68, 99-107.

Moury, B., Morel, C., Johansen, E., Guilbaud, L., Souche, S., Ayme, V., Caranta, C., Palloix, A., Jacquemond, M., 2004. Mutations in Potato virus $Y$ genome-linked protein determine virulence toward recessive resistances in Capsicum annuum and Lycopersicon hirsutum. Mol. Plantmicrobe Interact. 17, 322-329.

Sanjuan, R., Nebot, M.R., Chirico, N., Mansky, L.M., Belshaw, R., 2010. Viral mutation rates. J. Virol. 84, 9733-9748.

Sikorski, R.S., Hieter, P., 1989. A system of shuttle vectors and yeast host strains designed for efficient manipulation of DNA in Saccharomyces cerevisiae. Genetics 122, 19-27

Youssef, F., Marais, A., Faure, C., Gentit, P., Candresse, T., 2011. Strategies to facilitate the development of uncloned or cloned infectious full-length viral cDNAs : Apple chlorotic leaf spot virus as a case study. Virol. J. 8, 488.

Wetzel, T., Candresse, T., Macquaire, G., Ravelonandro, M., Dunez, J. 1992. A highly sensitive immunocapture polymerase chain reaction method for plum pox virus detection. J. Virol. Methods 39, 27-37. 


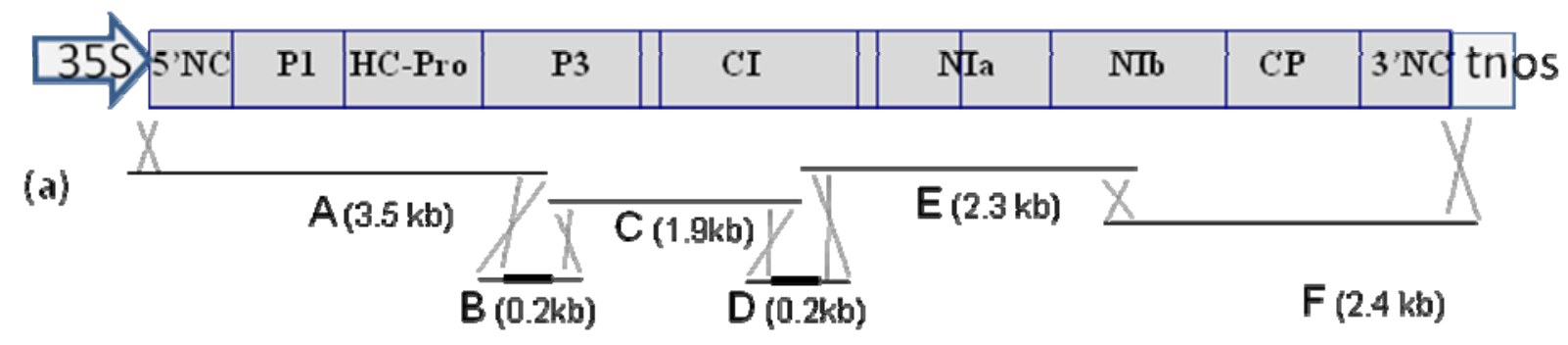

(b)

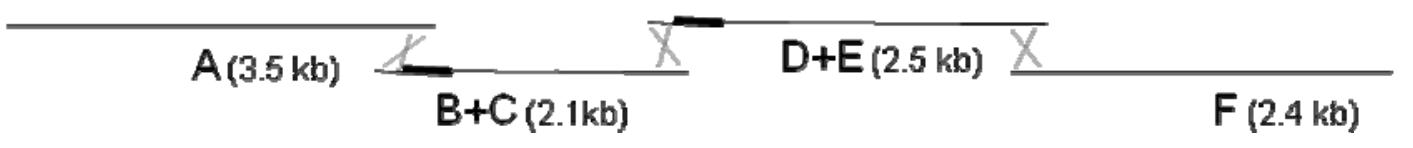

Figure 1: Cloning strategy for WMV

(a) Cloning of WMV genome using homologous recombination in yeast, with 4 genomic fragments overlapping the complete genome (fragments A, C, E, F) and 2 introns (fragments $\mathrm{B}$ and $\mathrm{D})$, in a shuttle vector containing a $35 \mathrm{~S}$ promoter and nos terminator

(b) Introns $\mathrm{B}$ and $\mathrm{D}$ were fused to fragments $\mathrm{C}$ and $\mathrm{E}$ respectively by fusion PCR before cloning 
Version définitive du manuscrit publié dans / Final version of the manuscript published in : Journal of Virological Methods, 2012, 183, 94-97, http://dx.doi.org/10.1016/j.jviromet.2012.03.035.

Table 1 : Primers used for PCR amplification of WMV, ZYMV and PRSV

\begin{tabular}{|c|c|c|}
\hline Primer & Position & Sequence \\
\hline WMV-A-FW & 1 & ATATAAGGAAGTTCATTTCATTTGGAGAGGAAATTAAAACAACTCATAAAGAC \\
\hline WMV-A-RV & 3522 & CTCGCACTGATGCAGTCCAAGC \\
\hline WMV-B-FW & 3514 & GTGACCAAGCTTGGACTGCATCAGTGCGAGGTAAGTTTCTGCTTCTACC \\
\hline WMV-B-RV & 3544 & GTAGCGTTGCTATGATAAATCTGACAAAACCTGCATATCAACAAATTTTG \\
\hline WMV-C-FW & 3541 & CTCGCACTGATGCAGTCCAAGC \\
\hline WMV-C-RV & 5403 & CTGATGTGGTATAGCCAACTTGTG \\
\hline WMV-D-FW & 5397 & ATGCTACACAAGTTGGCTATACCACATCAGGTAAGTATGCACTTAAAGA \\
\hline WMV-D-RV & 5427 & TCTTTCACTGATATCCATTGCCCGACAAACTGCATAATTTCAAAGATTG \\
\hline WMV-E-FW & 5428 & TTTGTCGGGCAATGGATATC \\
\hline WMV-E-RV & 7763 & ATTGAGCACCGACAGCAGC \\
\hline WMV-F-FW & 7659 & TTCGAGAAGGCAGTCGAGGG \\
\hline WMV-F-RV & 10017 & GCGAATCTAGATTTTTTTTTTTTTTTTTTTTAGGACAACAAACATTACCG \\
\hline ZYMV-A-FW & 1 & TATAAGGAAGTTCATTTCATTTGGAGAGG AAATTGAAACAAATCACAAAG \\
\hline ZY-3100-RV & 3124 & ACAAGTTCCGACGAGAGCC \\
\hline ZY-3060-FW & 3058 & ATCACGACCCGAGTACATG \\
\hline ZY-5370-RV & 5370 & GARTCAGCAATTCCAGCRAG \\
\hline ZY-5080-FW & 5081 & GGAGTGCACGTTCAATGCCA \\
\hline ZY-7550-RV & 7531 & CGTGTTTTGTTAGCCCTGAC \\
\hline ZY-7500-FW & 7481 & AAGGGTCTGTGGAATGGATC \\
\hline ZY-3NC-RV & 9582 & GCGAATCTAGATTTTTTTTTTTTTTTTTTTTAGGCTTGCAAACGGAGTC \\
\hline PRSV-A-FW & 1 & ATAAGGAAGTTCATTTCATTTGGAGAGG AAATAAAACATCTCAACACAAC \\
\hline PRSV-2670-RV & 2670 & CTTRGGATCACCAGAATTACC \\
\hline PRSV-2550-FW & 2550 & GGACCAATYACTCGTGAGTG \\
\hline PRSV-5230-RV & 5230 & TCAAGTGTGACGCCATTCTC \\
\hline PRSV-5210-FW & 5210 & AAGAAGCATTTCATAGTTGCCAC \\
\hline PRSV-8020-RV & 8020 & GCTCCRACWGCTGCATCCAT \\
\hline PRSV-7820-FW & 7280 & CCACTTATGGGTCACTAYATG \\
\hline PRSV-3NC-RV & 10311 & GCGAATCTAGATTTTTTTTTTTTTTTTTTTTTCTCTCATTCTAAGAGG \\
\hline
\end{tabular}

Underlined sequences correspond to the extremities of the introns. Sequences in italics correspond to the extremities of the vector. 